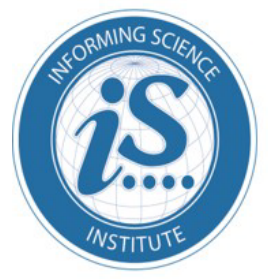

Interdisciplinary Journal of Information, Knowledge, and Management

An Official Publication

of the Informing Science Institute

InformingScience.org

IJIKM.org

Volume 12, 2017

\title{
RESEARCH FoCI, METHODOLOGIES, AND THEORIES USED IN ADDRESSING E-GOVERNMENT ACCESSIBILITY FOR PERSONS WITH DISABILITIES IN DEVELOPING COUNTRIES
}

\author{
Millicent Agangiba* \\ Department of Information Systems, \\ agnmil001@myuct.ac.za \\ University of Cape Town, Cape Town, \\ South Africa \\ Salah Kabanda \\ Department of Information Systems, \\ salah.kabanda@uct.ac.za \\ University of Cape Town, Cape Town, \\ South Africa
}

* Corresponding author

\begin{abstract}
Aim/Purpose

The purpose of this paper is to examine the key research foci, methodologies, and theoretical perspectives adopted by researchers when studying Egovernment accessibility for persons with disabilities (PWDs), particularly in developing countries. The study aims to develop a conceptual framework for designing accessible E-government for PWDs in developing countries.

Background

Studies on E-government accessibility for persons with disabilities in developing countries have been minimal. The few studies conducted until now have failed to integrate PWDs, a population already marginalized, into the digital society. Accessibility has been identified by researchers as a major hindrance to PWDs participating in E-government. It is imperative therefore to examine the manner in which researchers investigate and acquire knowledge about this phenomenon.

Methodology The study synthesizes literature from top IS journals following a systematic literature review approach. The data synthesis focuses on identifying key concepts relating to E-government accessibility for PWDs.

Contribution The study contributes to the field of E-government, with a focus on how Egovernment services can be made accessible to PWDs. The study calls on researchers to reflect on their epistemological and ontological paradigms when examining accessibility of E-government services in developing countries.
\end{abstract}

Accepted by Editor Jörg Lässig| Received: September 15, 2016 | Revised: January 26, May 3, July 5, August 15, September 3, 2017 | Accepted: September 4, 2017.

Cite as: Agangiba, M., \& Kabanda, S. (2017). Research foci, methodologies, and theories used in addressing egovernment accessibility for persons with disabilities in developing countries. Interdisciplinary Journal of Information, Knowledge, and Management, 12, 245-268. Retrieved from http://www.informingscience.org/Publications/3853

(CC BY-NC 4.0) This article is licensed to you under a Creative Commons Attribution-NonCommercial 4.0 International License. When you copy and redistribute this paper in full or in part, you need to provide proper attribution to it to ensure that others can later locate this work (and to ensure that others do not accuse you of plagiarism). You may (and we encourage you to) adapt, remix, transform, and build upon the material for any non-commercial purposes. This license does not permit you to use this material for commercial purposes. 
Findings

Recommendations for Practitioners

Recommendation for Researchers

Impact on Society

Future Research

Keywords
The findings show that most researchers focus on the evaluation of Egovernment websites and predominantly adopt quantitative methods. The study also reveals that the use of technological determinism as a theoretical lens is high among researchers.

The study recommends that E-government web developers and policy makers involve PWDs from design to evaluation in the development of E-government applications.

The study advocates the need to conduct studies on E-government accessibility by employing more qualitative and mixed approaches to gain in-depth and better understanding of the phenomenon.

This study creates greater awareness and points out inadequacies that society needs to address to make E-government more inclusive of and participatory for PWDs.

Further empirical work is required in order to refine the relevance and applicability of various constructs in EADM so as to arrive at a framework for addressing E-government accessibility for PWDs in developing countries.

\section{INTRODUCTION}

Globally there has been a paradigm shift in governance, such that ICT now plays a pivotal role in reforming the public sector. Traditionally, government interactions with citizens, businesses, and other agencies were mainly face-to-face, which quite often required extensive travel and queueing at government offices. Recently, however, the use of ICT in government, especially the Internet, has significantly evolved operations in government, making them faster and more efficient. E-government (Electronic or Digital government) is the application of ICTs, mobile devices, and particularly internet web-based applications by government, in order to simplify and optimize government procedures while delivering fast, accessible and efficient services to citizens, businesses and other government agencies (Kumar \& Sinha, 2007; Ndou, 2004; Ngulube, 2007). It is generally recognized that the advent of E-government has significantly reduced cost in government processes, eliminated bureaucratic machinery, minimized corruption, enhanced provision of services to the citizenry, and made government more responsive (Adesola, 2012; Aladwani, 2016; Mittal \& Kaur, 2013; Tolbert \& Mossberger, 2006). For example, E-government implementation in the US and Europe has helped to enhance the overall quality of services offered to citizens (Bertot, Jaeger, \& McClure, 2008; Weerakkody, Dwivedi, \& Kurunananda, 2009). This is also true for developing countries, where Egovernment has significantly helped to improve quality of services to citizens by eliminating some corrupt practices and speeding up internal government procedures (Basu, 2004; Hong, Trimi, Kim, \& Hyun, 2015; Kettani, 2014; Weerakkody et al., 2009).

A major distinction between E-government in comparison with other electronic services is that it should be accessible to all (Cumbie \& Kar, 2014; Kaaya, 2004; Schuppan, 2009). Lack of equal access has resulted in several umbrella terms of exclusion: info-exclusion, digital exclusion, and social exclusion (Joi, 2004; Muddiman, 2000; Watling, 2011). For E-government to be accessible, E-government web-based applications should be easy to interact with regardless of device (PC, webTV, mobile devices) and be compatible with the assistive technologies, which persons with disabilities (PWDs) may employ (Henry, Abou-zahra, \& Brewer, 2014; Shi, 2007; West, 2008). It is particularly crucial for PWDs, who tend to be marginalized from the population mainstream, to be integrated into the digital society where they can enjoy equal access to online opportunities, thereby creating independence, feelings of belonging, self-esteem, and even self-actualization (Cumbie \& Kar, 2014; Rubaii-Barrett \& Wise, 2008). This is important, given that for several decades PWDs have been excluded from the rest of the society, materially deprived, politically disenfranchised, and have faced social stigmatiza- 
tion due to segregation (Sullivan, 2011). If accessibility is not addressed in the era of E-government, PWDs risk being excluded and, in effect, governments will continue replicating the exclusions of previous eras (Jaeger, 2006). However, accessing online content comes with additional cost burdens for most PWDs (who may have visual, hearing, cognitive and/ or mobility impairment) who require different forms of assistive technologies and devices to enhance their functional capabilities (Boussarhan \& Daoudi, 2014; Henry et al., 2014; Jacko \& Vitense, 2001). Assistive technologies and devices such as tactile interfaces for visually impaired screen readers in computers (e.g., JAWS, NVDA), braille displays, speech synthesizers, tactile screens, magnification software, embossers, screen readers for mobile phones (e.g., TALKs, Mobile Speak), and character recognition scanners (Boussarhan \& Daoudi, 2014; Jacko \& Vitense, 2001) refer to any software or hardware that helps to increase, maintain, and improve functional capabilities for PWDs (Pal et al., 2010). When Egovernment portals are designed without PWDs in mind, it becomes difficult for such persons to use them, if these websites are not compatible with the assistive technologies they use (Stewart, Narendra, \& Schmetzke, 2005 West, 2008).

Several researchers on E-government accessibility have advocated for government to take steps to address the needs of PWDs by adopting appropriate technologies for E-government development (Heeks, 2005; Otniel, 2015; Stewart, Narendra, \& Schmetzke, 2005) and providing affordable assistive technologies and the necessary training involved for PWDs (Cumbie \& Kar, 2014; Disability Rights Commission, 2004; Dobransky \& Hargittai, 2006). Until now however, developing countries have made little progress in the provision of inclusive E-government services particularly towards PWDs (Adepoju \& Shehu, 2016; Baowaly \& Bhuiyan, 2012; Ismailova, 2017) despite the fact that $80 \%$ of the world's population with disabilities reside here (UNESCO, 2014). Few studies have documented how E-government fails to address accessibility for all, and this is a problem given the fact that globally governments are advancing in the provision of online services; PWDs risk being excluded (Albalushi, Ali, Ashrafi, \& Albalushi, 2016; Rubaii-Barrett \& Wise, 2008). Failure to resolve accessibility issues will create another disability - "digital disablement" - in addition to people's physical disablement (Chaudhry \& Shipp, 2005). If E-government accessibility remains a challenge in developing countries, it is in the best interest of researchers to interrogate how they acquire their understanding of E-government accessibility for PWDs. This is because the manner in which researchers acquire knowledge influences their understanding of the subject (Beckwith, Dickinson, \& Kendall, 2008; Dixit \& Stump, 2011; Tan, Wilson, \& Olver, 2009). The approach adopted by a researcher to acquire knowledge about a phenomenon comprises a set of assumptions about the nature of the phenomenon to be investigated, the methods he/she uses to understand the phenomenon, and the kind of knowledge formed (Morgan \& Smircich, 1980).

With this in mind, the present study examines how knowledge about E-government accessibility is arrived at - specifically, how researchers go about investigating the phenomenon. The paper therefore pays particular attention to E-government accessibility in developing countries and seeks to (1) identify and categorize the different research foci; (2) identify what ontological stance researchers adopt in examining this phenomenon; and (3) propose a conceptual model to improve Egovernment accessibility for PWDs.

The rest of the paper is structured as follows: first, related studies on E-government in developing countries are presented. The paper then describes epistemological and ontological approaches used in IS research. This is followed by the explication of the research methodology used in the study. Next, the findings of the literature synthesis are presented, followed by discussion on the findings. Finally, conclusions and limitations of the research are presented.

\section{RELATED Work ON E-gOVERNMENT IN DEVELOPING Countries}

Over the past years, several research studies have been conducted on E-government in developing countries. E-government is seen as a necessary tool for improved governance especially in developing countries, where corruption in government is perceived to be high (Bal, Biricik, \& Sari, 2015; Gupta 
\& Jana, 2003; Mistry \& Jalal, 2012). It is thought that E-governments in developing countries have the potential of improving quality of government services to citizens as well as government-citizen interactions (Basu, 2004; Malik, Shuqin, Mastoi, Gul, \& Gul, 2016; Ndou, 2004). Most cited benefits of E-governments include the provision of fast and efficient service to citizens at a reduced cost (Agangiba \& Agangiba, 2013; Mittal \& Kaur, 2013). E-government also helps to promote transparent and effective governance (Malik et al., 2016; Tolbert \& Mossberger, 2006). It is perceived that adoption of E-government improves resource management and accountability (Fang, 2002; Stanforth, 2006). E-government has the potential to empower citizens and make governance more inclusive (Gyaase \& Gyamfi, 2012; Rubaii-Barrett \& Wise, 2008). As a result, developing countries have made and continue to make significant investments into E-government to harness these benefits (Bhatnagar \& Singh, 2010). For developing countries, particularly those in Africa, to gain maximum benefit from E-government, its implementation needs to be context-oriented (Heeks, 2005; Mutula, 2013; Schuppan, 2009), citizen-centered (Bertot et al., 2008) and socially inclusive; (Makoza \& Chigona, 2013). There is also the need for strong institutions and legal frameworks (Basu, 2004; Heeks, 2003; Rorissa \& Demissie, 2010). This is because E-government in developing countries still faces numerous challenges, such as limited ICT infrastructure, lack of human capacity, low literacy rate, and limited accessibility, among others (Mittal \& Kaur, 2013; Rorissa \& Demissie, 2010) as shown in Table 1. For example, the challenge of human capacity in ICT is a dire problem in many developing countries. According to Chen, Chen, Huang, \& Ching (2006), the lack of human capacity is one aspect that differentiates E-government success in developed and developing countries. To address this problem, Asongu and Le Roux (2017) call for policies designed to boost ICT (mobile phone, internet, telephone) penetration, which will in turn develop inclusivity. Such policies need to create awareness and address issues around "attitude, learning content/resources, accessibility, trust, public support, knowledgeable personnel, gender inequality, low citizen participation, training and capacity building" (Nkohkwo \& Islam, 2013, p. 258).

Table 1: Summary of some E-government challenges in developing countries

\begin{tabular}{|l|l|l|}
\hline E-government challenges & Proposed strategies & Source \\
\hline Lack of human capacity & $\begin{array}{l}\text { Design policies to boost ICT } \\
\text { (mobile phone, internet, tele- } \\
\text { phone) penetration }\end{array}$ & $\begin{array}{l}\text { Ebrahim \& Irani, 2005; Ndou, } \\
\text { 2004; Rorissa \& Demissie, 2010 }\end{array}$ \\
\hline Design-reality-gap & STOPE and AHP framework & $\begin{array}{l}\text { Choi, Jae, Jeung, \& Zo, 2016; } \\
\text { Heeks, 2005; Janssen, Van Der } \\
\text { Voort, \& van Veenstra, 2015; } \\
\text { Verdegem \& Verleye, 2009; }\end{array}$ \\
\hline Accessibility & $\begin{array}{l}\text { Provide easy access to ICTs, } \\
\text { develop and implement accessi- } \\
\text { bility guidelines for E- } \\
\text { government developers }\end{array}$ & $\begin{array}{l}\text { Adepoju \& Shehu, 2016; Basu, } \\
\text { 2004; Hoque \& Sorwar, 2015; } \\
\text { Makoza \& Chigona, 2013 }\end{array}$ \\
\hline Lack of infrastructure & $\begin{array}{l}\text { Set up stable telecommunica- } \\
\text { tions backbone, access to Inter- } \\
\text { net, stable power supply }\end{array}$ & $\begin{array}{l}\text { Mittal \& Kaur, 2013; Nkohkwo } \\
\text { \& Islam, 2013; Rorissa \& } \\
\text { Demissie, 2010 }\end{array}$ \\
\hline Lack of legal framework & $\begin{array}{l}\text { Political willingness to imple- } \\
\text { ment smart E-government and } \\
\text { ICT policies }\end{array}$ & $\begin{array}{l}\text { Basu, 2004; Rorissa \& Demissie, } \\
\text { 2010; Thakur \& Singh, 2013 }\end{array}$ \\
\hline $\begin{array}{l}\text { Corruption and inadequate } \\
\text { funds }\end{array}$ & $\begin{array}{l}\text { Effective planning of E- } \\
\text { government projects and re- } \\
\text { striction of monitoring and } \\
\text { evaluation of projects }\end{array}$ & $\begin{array}{l}\text { Aladwani, 2016; Schuppan, 2009; } \\
\text { Stanforth, 2006 }\end{array}$ \\
\hline
\end{tabular}

Another challenge in developing countries according to Heeks (2005, p. 63), is the fact that most Egovernment projects fail due to a gap in "design and reality" - which concerns "hard-soft gaps (be- 
tween technology and social context); private-public gaps (differences between the public and the private sector); and country context gaps (variances between counties)" (Anthopoulos, Reddick, Giannakidou, \& Mavridis, 2016, p. 164). Researchers have noted how current studies fail to highlight the impact of E-government projects, and evaluations of such projects remains rare (Mates, Lechner, Rieger, \& Pěkná, 2013), with literature dedicated to E-government strategies and implementations predominantly adopting the perspectives of developed countries rather than those of developing countries. Choi et al. (2016) propose the strategy, technology, organization, people, and environment (STOPE) framework (adopted specifically for developing countries), combined with the analytic hierarchy process (AHP) as an assessment method for E-government implementation in developing countries to enable both ex-ante and ex-post evaluations that apply to entire E-government systems and to subsystem projects.

Table 1 highlights accessibility as one of the hindrances which makes E-government services difficult to reach all citizens (Basu, 2004; Cumbie \& Kar, 2014). For example, accessibility issues have resulted in digital divide and disparity in E-government service provision between urban and rural settlements (Hoque \& Sorwar, 2015). Thus, a focus on accessibility for PWDs is of paramount importance because "the power of the Web is in its universality. Access by everyone regardless of disability is an essential aspect" (Berners-Lee, 1997). Accessible E-government services have the potential of creating independence, self-actualization, and promoting PWDs' social inclusion (Makoza \& Chigona, 2013; Rubaii-Barrett \& Wise, 2008). Until now, however, most E-government accessibility studies have focused on developed countries; with developing countries, particularly in Africa, receiving the least attention (Adepoju \& Shehu, 2016; Baowaly \& Bhuiyan, 2012). Since there are mostly no alternative providers of specific E-government services (Leist \& Smith, 2014), PWDs will become increasingly disadvantaged as governments advance in providing more sophisticated services online (Cumbie \& Kar, 2014; Jaeger, 2006; Rubaii-Barrett \& Wise, 2008). To address the problem of accessibility, several researchers recommend, among others, the provision of easy access to ICTs, development of and implementation of accessibility guidelines for E-government developers.

Additional challenges for E-Government in Africa have been around the lack of infrastructure, legal framework, corruption, and inadequate funds. Consistent strategies proposed in literature to address the infrastructure and legal challenges have been the setup of a stable telecommunications backbone, access to Internet, and the provision of stable power supply, as well as government investing in their political will to address E-government challenges. Effective planning of E-government projects and restrictive monitoring and evaluation of projects are seen as a potential solution to addressing corruption and inadequate funds challenges (Aladwani, 2016; Schuppan, 2009; Stanforth, 2006). Yet, despite the many solutions presented for the challenges facing Africa, and the continuous government investment in E-government, most E-government projects remain unsuccessful (Heeks, 2003). There is thus a need to examine how researchers go about investigating the E-government accessibility phenomenon in developing countries. In the quest to address equal access to online services, several practical guidelines have been proposed: the use of automatic tools, understanding website implementers, and the use of models. With the use of automatic tools, researchers are able to identify barriers perceived to be inherent with regard to accessibility. Understanding the website implementer's perspective on the accessibility is crucial, since perception can shape attitude and ultimately the implementation of an accessible website. The use of models guide researchers to identify gaps in their understanding of the phenomenon of accessibility (Bloch \& Richins, 1983).

\section{AUTOMATIC TOOLS}

Accessibility of E-government is mostly assessed through the evaluation of E-government websites. These websites can be evaluated using automatic tools (e.g., EvalAccess, TAW, AChecker) to test their compliance with international standards such as the Web Content Accessibility Guidelines (WCAG) or legal requirements such as Section 508 of the Rehabilitation by the US Congress (Olalere \& Lazar, 2011). WCAG explain how to make information in a web page or web application more accessible to PWDs (http://www.w3.org/WAI/intro/wcag). Scholars who used this approach include Adepoju 
and Shehu (2016), Ismailova (2017), Bousarhan and Daoudi (2014), Olalere and Lazar (2011), Jaeger (2006), and Abanumy, Al-badi, and Mayhew, (2005). They all report lack of conformity in the websites to the WCAG guidelines. Although these guidelines provide stakeholders with a means for addressing accessibility, the implementation of these tools and guidelines presents unique challenges. For example, "it is readily possible for an individual to find a particular web resource accessible on one platform, say a smart phone, but presenting them with accessibility challenges or barriers on different platforms, say a PC or web-enabled TV" (Cooper, Sloan, Kelly, \& Lewthwaite, 2012). Other challenges highlighted by Alonso, Fuertes, González, and Martínez (2010) include accessibility supported technologies, testability of success criteria, openness of techniques and failures, and the aggregation of partial results. Power, Freire, Petrie, and Swallow (2012) found that although some of the problems encountered by users were covered by the WCAG, the techniques recommended in WCAG did not solve all the problems of users. The implication is that even if these best practice tools and guidelines are implemented on websites, "there is little indication that PWDs will encounter fewer problems" (Power et al., 2012, p. 433).

\section{WEB MASTERS AND WEB DEVELOPERS AS KEY STAKEHOLDERS}

Given that accessibility tools are directed at those who design and develop websites it is important to include them as participants, so as to assess their views on accessibility, and not merely as "vehicles" who facilitate accessibility of websites. Webmasters and web developers' perception and awareness of the need for accessibility can influence design (Baguma, Wanyama, Bommel, \& Ogao, 2007; Freire, Russo, \& Fortes, 2008). For example, Evans-Cowley (2006) surveyed webmasters about the accessibility of 100 large municipal websites in USA. The results show that $87 \%$ of webmasters are familiar with section 508 which requires websites to be accessible for PWDs, but only $18 \%$ of the webmasters follow these standards. Power et al. (2012, p. 433) note that "despite awareness of accessibility increasing over the last decade at the level of government and legislation, the level of knowledge in the community of web commissioners and web masters remains quite low." The implication is that the role of accessibility tools and related guidelines remained unclear to stakeholders and this could have a negative consequence on how they design, develop, and maintain a website. Jaeger's (2006) study on webmasters' perceptions of the accessibility of their websites revealed that webmasters' perceptions often did not match the findings of the user testing and the expert testing. He found that problems of communication existed between the providers of E-government websites and the users of E-government websites. These findings, according to Jaeger (2008) were problematic, both in terms of accessibility and in terms of larger issues of the overall responsiveness and transparency of E-government.

\section{THE USE OF MODELS}

For the purpose of structure and a framework of reference, researchers have proposed four main models to address accessibility for PWDs: Composite Practice Model (Leung et al., 1999), Holistic Model (Kelly, Phipps, \& Howell, 2005), Contextualized Model (Seale, 2006) and the Web Accessibility Integration Model (Lazar, Dudley-sponaugle, \& Greenidge, 2004). The Composite Practice Model is an approach that lays emphasis on assistive technologies to address accessibility and service delivery for PWDs. Leung et al. (1999) used CPM to describe and explain current practice in regard to assistive technologies service delivery in post-secondary educational settings across Australia. The model's strength is in how effectively it highlights the contribution of a range of stakeholders.

The Holistic Model approach places PWDs at the core of accessibility development, which helps to provide accessibility for diverse disabilities (Kelly et al., 2005). The model focuses on the individual needs of the disabled, providing solutions either via electronic or alternative means and taking into consideration the resources available to the individual. Kelly et al. (2005) used the holistic model to understand accessibility in E-learning. The Contextualized Model argues that accessibility is a practice or activity that can and will be mediated (Seale, 2006). As a practice, it consists of three components of accessibility: stakeholders of accessibility, contexts in which these stakeholders have to operate, 
and how the relationship between the stakeholders and the context influences the responses they make and the accessible practices that develop. Stakeholders' responses to or practices of accessibility are mediated by the context in which they operate.

Lazar et al. (2004) propose the Web Accessibility Integration Model (WAIM), which is based on technological determinism and a methodological approach grounded on conformance to guidelines. WAIM describes various components that influence web accessibility such as societal values, stakeholders, and web development process (Lazar et al., 2004). The model describes various ways in which accessibility flaws enter design and how to make the web a more accessible place. Although these models have adequately addressed issues of accessibility, they have done so in the context of E-learning and not specifically in the context of E-government. Table 2 provides a summary of the various approaches used in understanding accessibility of E-government services. The approach adopted by researchers in studying E-government accessibility is informed by their epistemological and ontological stances. These stances reflect in the methods used and subsequently the knowledge acquired.

Table 2: Summary of approaches used in E-government accessibility studies

\begin{tabular}{|c|c|c|}
\hline Approach & Benefit & Challenges \\
\hline Automatic Tools & $\begin{array}{l}\text { Uses software such as TAW, } \\
\text { EvalAccess to evaluate E- } \\
\text { government websites' compli- } \\
\text { ance with specific accessibility } \\
\text { standard } \\
\text { Outcome leads to detection of } \\
\text { accessibility errors in the design } \\
\text { of websites which require retro- } \\
\text { fitting }\end{array}$ & $\begin{array}{l}\text { Does not involve E- } \\
\text { government stakeholders } \\
\text { - Can produce inconsistent } \\
\text { results }\end{array}$ \\
\hline $\begin{array}{l}\text { Webmaster's/ Develop- } \\
\text { ers' Perception }\end{array}$ & $\begin{array}{l}\text { This approach helps researchers } \\
\text { understand accessibility from } \\
\text { the perspective of webmasters/ } \\
\text { web developers who design and } \\
\text { maintain E-government web- } \\
\text { sites } \\
\text { - Outcome results in the creation } \\
\text { of more awareness of accessi- } \\
\text { bility for webmasters / develop- } \\
\text { ers and improved web design } \\
\text { practices }\end{array}$ & $\begin{array}{l}\text { Involves at least one E- } \\
\text { government stakeholder } \\
\text { (webmaster/ web devel- } \\
\text { oper) while other stake- } \\
\text { holders are side-lined } \\
\text { Different webmasters/ } \\
\text { developers interpret acces- } \\
\text { sibility guidelines differ- } \\
\text { ently due the ambiguous } \\
\text { nature of the accessibility } \\
\text { guidelines and their re- } \\
\text { spective training; as such } \\
\text { they hold varying percep- } \\
\text { tions }\end{array}$ \\
\hline Models & $\begin{array}{l}\text { Models help researchers to } \\
\text { identify accessibility barriers or } \\
\text { gaps } \\
\text { Help to better understand the } \\
\text { intertwined relationship among } \\
\text { different stakeholders } \\
\text { - Outcome is multi-dimensional; } \\
\text { varying from stakeholder to } \\
\text { stakeholder to provide accessi- } \\
\text { bility solution }\end{array}$ & $\begin{array}{l}\text { Addressing accessibility } \\
\text { barriers require the in- } \\
\text { volvement of several } \\
\text { stakeholders including } \\
\text { PWDs }\end{array}$ \\
\hline
\end{tabular}




\section{EPISTEMOLOGICAL AND ONTOLOGICAL APPROACHES IN IS RESEARCH}

In social science and IS studies, researchers tend implicitly or explicitly to use a specific intellectual stance to gain understanding of a phenomenon. Every researcher adopts a paradigm to conduct research, which embeds in itself an ontological and epistemological perspective (Orlikowski \& Baroudi, 1991). Based on their ontological stance, researchers make claims in respect of what exists or they perceive exists (Creswell, 2003). Reality could be objective or subjective, depending on interpretation; reality is considered to be either empirically verifiable or not (Cua \& Garrett, 2008). Epistemology refers to how a researcher acquires, creates, or communicates knowledge about a particular problem or phenomenon and how to obtain an understanding that is valid (Hirschheim, 1985). Ontological and epistemological assumptions of a researcher relate to the methodology and methods he or she chooses (Scotland, 2012). According to Cua and Garret (2008) epistemology and ontology overlap in the methodology used. Three main ontological approaches are defined in IS: quantitative, qualitative, and mixed method. Each ontological paradigm has an underlying research epistemology. In IS research, three common epistemological paradigms are adhered to: positivistic (or conventional), constructivist (or interpretive) and critical paradigm (Cua \& Garrett, 2008; Kanellis \& Papadopoulos, 2009; Myers \& Klein, 2011; Orlikowski \& Baroudi, 1991). These paradigms tend to have considerable impact on how validity, reliability, and rigor of the research is understood (Becker \& Niehaves, 2007).

Quantitative researchers argue that existing truth or knowledge is objective and can be measured (Creswell, 2003). They contend that a researcher is independent of the objects being observed. A common epistemological paradigm associated with quantitative researchers is Positivism. Positivists argue that knowledge can be expressed in terms of facts that are empirically validated by measurement (Hirschheim, Klein, \& Lyytinen, 1995). This paradigm is premised on stable or fixed relationships between objects, which are investigated using structured instrumentation in an attempt to test a theory or hypothesis; furthermore drawing inferences from a large population in order to produce a generalizable result (Orlikowski \& Baroudi, 1991). Positivists adopt deterministic explanations of phenomena, postulate that data is value-free and reject the idea that humans are active makers of their social world (Guba \& Lincoln, 1994; Orlikowski \& Baroudi, 1991).

Qualitative researchers, on the other hand, argue that knowledge is socially constructed within a context, so that data cannot be "value-free data" (Walsham, 1995, p. 376). Qualitative research seeks to understand the phenomenon of interest from the participants' perspective through in-depth interaction in their given social and cultural context (Kaplan \& Maxwell, 1994; Morgan \& Smircich, 1980). Interpretivism and critical research are two paradigms that follow qualitative methodology (Myers, 1997). Interpretivism posits objects exist to the extent to which you perceive them; in effect, our perceptions shape the reality (Kelliher, 2011; Orlikowski \& Baroudi, 1991). The objective of an interprevist is to produce understanding of a phenomenon within a particular culture and context; examining phenomena in their natural setting through the meanings participants assign to them (Kaplan \& Maxwell, 2005; Walsham, 1995). Reality is not independent of the researcher, but is rather "an emergent social process, ... an extension of human consciousness and subjective experience" (Burell \& Morgan, 1979, p. 253). A critical paradigm, by extension, does not seek only to develop explanations or understanding of phenomenon but extends to critique the phenomenon under investigation and help transform social conditions (Myers \& Klein, 2011; Ngwenyama \& Lee, 1997). It seeks to emancipate and opposes every form of power and discrimination; however, it is constrained by systems of political, economic and cultural authorities (Orlikowski \& Baroudi, 1991). Critical research opposes the separation of value and inquiry; critical research focuses on emancipation of humans (Ngwenyama, 1991).

Research sometimes may require both objective and subjective views of reality. At this point, subjectivity and objectivity becomes inseparable; for example, to study and understand a phenomenon like poverty, objectively one can measure this through income levels, but the stigma and shame attached to poverty can only be understood through the perceptions of individuals in that state, which is socially constructed. It becomes clear therefore that sometimes research cannot be purely quantitative 
or qualitative, but must adopt a mixed approach. Mixed approach produces triangulation, through the use of multiple data sources (Markus, 1994). All diversities in terms of the problems addressed, theoretical foundations, means of data collection, and interpretation are useful in increasing rigor and output in IS researches (Benbasat \& Weber, 1996). Table 3 summaries the three epistemological paradigms discussed.

Table 3: Summary of epistemological paradigms

\begin{tabular}{|l|l|l|}
\hline \multicolumn{1}{|c|}{ Positivism } & \multicolumn{1}{|c|}{ Interpretivism } & \multicolumn{1}{c|}{ Critical } \\
\hline $\begin{array}{l}\text { Underlying ontological as- } \\
\text { sumption is mainly quantita- } \\
\text { tive }\end{array}$ & $\begin{array}{l}\text { Underlying ontological assump- } \\
\text { tion is mainly qualitative }\end{array}$ & $\begin{array}{l}\text { Underlying ontological as- } \\
\text { sumption is mainly qualitative }\end{array}$ \\
\hline $\begin{array}{l}\text { Reality is objective and pro- } \\
\text { jected as a definite structure }\end{array}$ & $\begin{array}{l}\text { Reality is subjective and socially } \\
\text { constructed i.e. a projection of } \\
\text { the human imagination }\end{array}$ & $\begin{array}{l}\text { Reality is historically con- } \\
\text { structed with internal influ- } \\
\text { ences such as politics, eco- } \\
\text { nomics }\end{array}$ \\
\hline $\begin{array}{l}\text { Aims to study a system, pro- } \\
\text { cesses and change }\end{array}$ & $\begin{array}{l}\text { Aim to understand, explore and } \\
\text { discover reality }\end{array}$ & $\begin{array}{l}\text { Aims at finding alternative } \\
\text { social conditions to enhance } \\
\text { human life }\end{array}$ \\
\hline $\begin{array}{l}\text { It involves empirical analysis } \\
\text { of relationships in the exter- } \\
\text { nal world }\end{array}$ & $\begin{array}{l}\text { It is concerned with understand- } \\
\text { ing the processes through which } \\
\text { humans form specific relation- } \\
\text { ships }\end{array}$ & $\begin{array}{l}\text { It is concerned with critiquing } \\
\text { social conditions and how to } \\
\text { improve them }\end{array}$ \\
\hline $\begin{array}{l}\text { Measuring outcomes based on } \\
\text { causal relationships }\end{array}$ & $\begin{array}{l}\text { Understanding causal relation- } \\
\text { ships }\end{array}$ & Reasoning and critiquing \\
\hline Data is value-free & $\begin{array}{l}\text { Data is value-laden with human } \\
\text { judgment }\end{array}$ & $\begin{array}{l}\text { Data has explicit value on } \\
\text { improvement of human con- } \\
\text { ditions }\end{array}$ \\
\hline $\begin{array}{l}\text { Aims to generalize research } \\
\text { findings }\end{array}$ & $\begin{array}{l}\text { Aims to understand in-depth re- } \\
\text { search problem }\end{array}$ & $\begin{array}{l}\text { Aims to emancipate and im- } \\
\text { prove human conditions }\end{array}$ \\
\hline
\end{tabular}

The purpose of this study is to examine how knowledge about E-government accessibility is arrived at - specifically, how researchers go about investigating the phenomenon in developing countries. We seek to determine the consistent research themes on E-Government in developing countries, and the ontological and epistemological stances researchers adopt. The study does not focus on researchers' socially constructed thoughts and experiences which influence their understanding and the meaning that they ascribe to E-government accessibility in developing countries. As such, this study employs a positivist approach, because the researchers have not shared a "common human history and "lived experience' in a 'life-world' shaped by 'tradition' with those they study" (Butler \& O'Reilly, 2010, p. 6). The next section discusses the methodology used in this study, in a bid to identify research foci, methodological approaches and theoretical perspectives used by researchers in investigating Egovernment accessibility, and factors that influence E-government accessibility for PWDs, particularly in developing countries.

\section{METHODOLOGY}

\section{APPROACH AND DATA COLLECTION}

This study followed a systematic literature review synthesis of existing scholarly articles. According to Okoli and Schabram (2010) systematic literature review procedures include identification, evaluation, and synthesis of existing scholarly articles. These guidelines, they argue, are specifically designed for IS research to ensure rigor and reproducibility and, in addition, place emphasis on how researchers go about conducting research as part of review procedure. These guidelines are adopted in this study. 
This study focuses on analyzing journal publications, since they are often used by academics as a source of new knowledge (Nord \& Nord, 1995) and also serve as an indicator of scientific productivity (Legge \& Devore, 1987). This researcher selected specific journals and therefore could be subject to bias, since some useful articles - such as those in conference proceedings, book chapters and dissertations - that are of high quality and contextually relevant are omitted. Such an omission does not devalue the findings of this study, however, as the data collected covers a wide period (2000 2015) and therefore findings would provide a general picture of E-government accessibility in developing countries.

Data was collected from top-ranked IS journals on developing countries: 'Information Technology for Development', 'Information Technologies and International Development', 'Electronic Journal of IS in Developing Countries', 'African Journal of Information and Communication' and 'African Journal of Information Systems'. The study also included two popular disability journals: 'Disability Studies Quarterly' and 'Journal of Disability Policy Studies' (Heeks, 2010). 'The Government Information Quarterly' and the 'Electronic Journal of e-Government', which are top journals that address governance issues, were also searched. Studies and searches included only publications in English from the year 2000 - 2015. This period was chosen because issues of accessibility for PWDs with regards to online services gained much attention after the formulation of Web Content Accessibility Guidelines in 1999 (W3C, 1999). In addition, Google Scholar was used to assist with a broader search, drawing on literature which possibly was omitted using the databases. Search key terms used were specific to the main goal of the study: E-government accessibility for PWDs in developing countries. As such, the key terms used include E-government accessibility, E-government and disabilities, E-government in developing countries. Quotation marks were used to restrict searches to likely relevant articles; example E-government accessibility was searched "E-government accessibility". The initial search resulted in 356 papers from the eight journals. A complement search from Google Scholar resulted in an additional 22 articles, bringing the total articles to 378. Each of these journal articles became part of the data corpus for the study.

\section{ANALYSIS}

The analysis commenced with a reading of each of the articles to understand the article's goal and relevance to this study. Whilst doing this analysis, it was observed that some articles were dupli- or triplicated; the excess was discarded. For example, the article "Engaging Citizens with Disabilities in eDemocracy" appeared three times: when we searched by the keywords 'E-government accessibility', 'E-government and disabilities', 'E-government in developing countries' in the Journal of Disability Studies Quarterly. This exercise reduced the total number of articles in the data corpus to 316. At the next stage of analysis, 25 articles were excluded because they were administratively focused (i.e., editorials). Editorials are special issues by editors of journals where they briefly discuss articles that are published for a particular theme issue. For example, the 'African Journal of information and Communications' alone had 12 editorials each focusing on a particular theme of issue. After the process of editorial elimination, 291 articles remained for further analysis. Table 4 shows the summary of literature synthesis. Each of the remaining articles in the data corpus were synthesized in a specific manner to assess relevance to the study. The article's title, abstract, keywords, introduction, and conclusion were read, and articles whose focus was only on E-government accessibility were included for the next phase of analysis. This exercise once again substantially narrowed down the number of articles to 90 (see Column 5). The next phase of analysis focused on determining whether the articles were specific to PWDs and online government services. That is, only articles that focused on PWDs were included - those that were on E-government accessibility, but whose focus was not PWDs, were excluded. For example, Hoque and Sorwar (2015) examined the disparity between urban and rural towns in terms of accessing E-government services in Bangladesh. Thus, although the study addresses E-government and accessibility, the focus was not on the disabled, but rather on the digital divide. On this basis, a total of 62 papers were removed, making a data corpus of 28 articles (column 
6). The remaining articles were categorized into research foci, ontologies and research approaches concerning tools, models and stakeholder involvement, as shown in Table 5.

Table 4: Summary of literature synthesis

\begin{tabular}{|c|c|c|c|c|c|}
\hline Data source & $\begin{array}{l}\text { Initial } \\
\text { Search }\end{array}$ & $\begin{array}{l}\text { After Remov- } \\
\text { ing Multiples } \\
\text { of Identical } \\
\text { Articles }\end{array}$ & $\begin{array}{l}\text { After Re- } \\
\text { moving } \\
\text { Journal } \\
\text { Editorials }\end{array}$ & $\begin{array}{l}\text { Articles on } \\
\text { E-government } \\
\text { Accessibility }\end{array}$ & $\begin{array}{l}\text { Final } \\
\text { search } \\
\text { (Focus on } \\
\text { Disability) }\end{array}$ \\
\hline $\begin{array}{l}\text { Journal on Disability } \\
\text { Policy Studies }\end{array}$ & 14 & 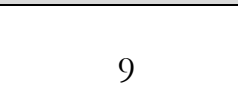 & 9 & 4 & 4 \\
\hline $\begin{array}{l}\text { Disability Studies } \\
\text { Quarterly }\end{array}$ & 18 & 15 & 13 & 4 & 4 \\
\hline $\begin{array}{l}\text { Information Technol- } \\
\text { ogies and International } \\
\text { Development }\end{array}$ & 58 & 45 & 37 & 6 & 0 \\
\hline $\begin{array}{l}\text { Journal of IT for De- } \\
\text { velopment }\end{array}$ & 46 & 37 & 37 & 8 & 2 \\
\hline $\begin{array}{l}\text { Electronic Journal of } \\
\text { e-Government }\end{array}$ & 40 & 40 & 40 & 34 & 5 \\
\hline $\begin{array}{l}\text { Electronic Journal of } \\
\text { IS in Developing } \\
\text { Countries }\end{array}$ & 40 & 29 & 28 & 3 & 1 \\
\hline $\begin{array}{l}\text { African Journal on } \\
\text { Information and } \\
\text { Communication }\end{array}$ & 93 & 72 & 60 & 0 & 0 \\
\hline African Journal of IS & 41 & 41 & 39 & 3 & 0 \\
\hline $\begin{array}{l}\text { Government Infor- } \\
\text { mation Quarterly }\end{array}$ & 6 & 6 & 6 & 6 & 4 \\
\hline Google Scholar & 22 & 22 & 22 & 22 & 8 \\
\hline Total & 378 & 316 & 291 & 90 & 28 \\
\hline
\end{tabular}

Table 5: Summary of Research Foci and Ontologies

\begin{tabular}{|c|c|l|}
\hline Theme & Number of Articles & \multicolumn{1}{c|}{ Observations } \\
\hline \multirow{5}{*}{ Research Focus } & 19 & $\begin{array}{l}\text { Evaluation: accessibility of E-government websites for } \\
\text { PWDs }\end{array}$ \\
\cline { 2 - 3 } & 3 & $\begin{array}{l}\text { Stakeholder Perception: } \text { E-government perceptions of } \\
\text { stakeholders in E-government accessibility }\end{array}$ \\
\cline { 2 - 3 } & 3 & \begin{tabular}{l} 
Policy Analysis: impact of policies on accessibility \\
\cline { 2 - 3 } Ontology
\end{tabular} \\
\cline { 2 - 3 } & 3 & $\begin{array}{l}\text { Social Exclusion: barriers to information access among } \\
\text { PWDs and how assistive technologies impact on ac- } \\
\text { cessibility }\end{array}$ \\
\hline \multirow{3}{*}{$\begin{array}{c}\text { Reolsearch } \\
\text { Webmasters }\end{array}$} & 23 & Quantitative: Website analysis, Questionnaires/Survey \\
\cline { 2 - 3 } & 2 & Qualitative: Observation, Interview \\
\cline { 2 - 3 } & 3 & Mixed Approach: Interviews, Survey, Website analysis \\
\hline
\end{tabular}




\section{FINDINGS}

\section{E-GOVERNMENT ACCESSIBILITY RESEARCH FOCI}

The findings showed that a significant number of studies $(67 \%)$ gave attention to the evaluation of E-government websites. That is, researchers tend to evaluate whether the websites are accessible to PWDs - for example, the ease with which PWDs can navigate through and access information. For instance, Bousarhan and Daoudi (2014) evaluated the accessibility of three Moroccan E-government websites using the automatic tool AccessiWeb. The study concluded that the websites do not meet the minimum criteria recommended by Web Content Accessibility Guidelines (WCAG) for PWDs, due to poor design and inappropriate use of technology. The other remaining 18 articles reported similar findings.

The remaining research foci received equal attention of 11\% each. The foci on Stakeholder perceptions examined stakeholders' perceptions of accessibility and argued that stakeholders' perceptions influenced the way they developed E-government websites. Freire et al. (2008) conducted a survey of 613 participants on accessibility in Brazil. The participants were mainly drawn from industry, academia, and government. Analysis of survey results indicated that accessibility awareness was very low, even though accessibility law in Brazil had been enacted for several years. This lack of awareness of accessibility by stakeholders according to Freire et al. (2008) accounted partly for accessibility challenges that PWDs faced. The study also revealed that participants in academia ranked at the top for stakeholders with the least awareness of accessibility.

Studies that focused on policy analysis examined the impact of policies on accessibility for PWDs. Such studies argued for the need to establish and monitor policies that ensure equal access to government information, particularly for PWDs. Kuzma, Yen, and Oestreicher (2009), for example, carried out a study to examine if the enforcement of disability laws has impact on accessibility of Egovernment for PWDs in twelve countries. Their study revealed that countries that have strong disability legislation are likely to have more accessible E-government than those that do not. The study found that countries in Africa such as Liberia, South Africa, Kenya, and Namibia provided the least accessibility, because of a weak legal mandate for PWDs.

Researchers whose focus is on policy analysis postulate that establishment of a law alone is insufficient to address accessibility; there is the need to monitor its implementation. Accessible web design in the era of E-government remains crucial for PWDs to be integrated into the digital society (Goodwin, Susar, Nietzio, Snaprud, \& Jensen, 2011). As a result, three researchers adopted the social exclusion lens to argue for equal access to government information for PWDs (Abu-doush, Banymohammed, Ali, \& Al-betar, 2013; Chaudhry \& Shipp, 2005; Cumbie \& Kar, 2014). According to Chaudhry and Shipp (2005), several levels of influence act as barriers for PWDs - for example, access to assistive technologies, poor web design, and a weak legal framework. These barriers, they argue, individually or collectively affect accessibility for PWDs and exclude them from having equal access to information. In a comparative study between India and the US, Chaudhry and Shipp (2005) showed that developing countries need more commitment to address socio-cultural issues in their quest to improve accessibility. They argue that technology alone is insufficient to address accessibility and called for holistic assessment to better understand the interplay between society, technology and PWDs in order to enhance accessibility. Figure 1 shows the various issues (research foci) identified from the literature synthesis that affect accessibility. 


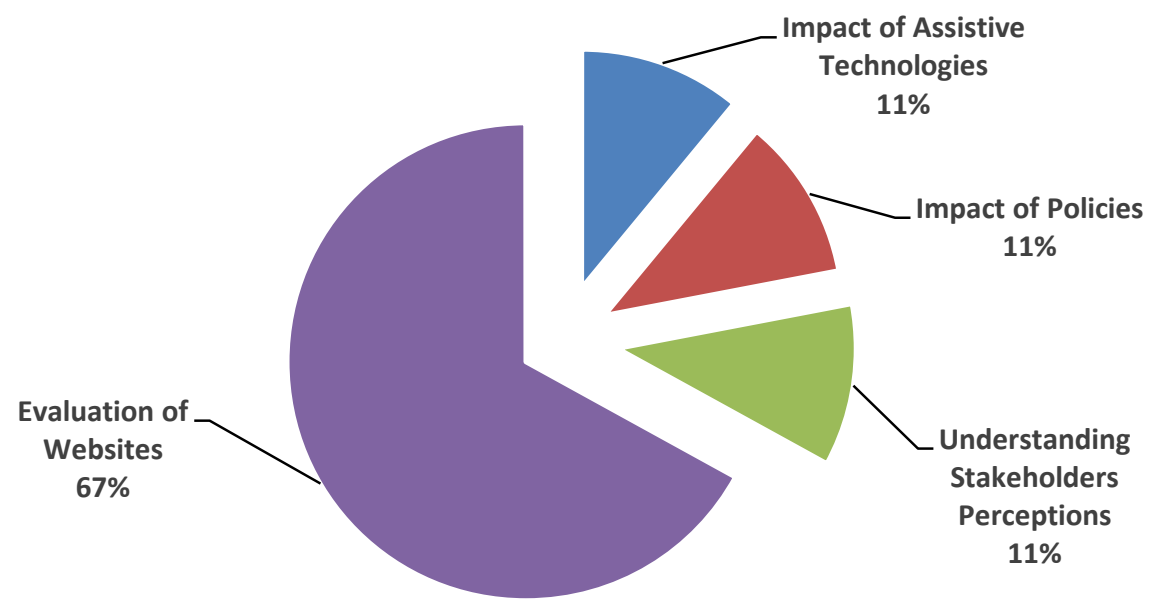

Figure 1: Summary of Research foci

\section{E-GOVERNMENT ACCESSIBILITY RESEARCH METHODOLOGIES}

Further findings from the analysis show that most researchers $(82 \%)$ used quantitative methods such as survey, website analysis, and questionnaires, and mostly aligned themselves with a positivist stance. Survey questionnaires were used mainly by researchers to elicit accessibility perception of Egovernment stakeholders (Baguma et al., 2007; Freire et al., 2008). For example, Baguma et al. (2007) conducted a survey of webmasters in Uganda to examine their knowledge and perceptions of accessibility.

Only two studies $(7 \%)$ employed qualitative methods to understand and interpret the accessibility phenomenon. For example, Ratliffe, Rao, Skouge, and Peter (2012) investigated how best to integrate PWDs into our digital society. The study highlights themes of collaboration, access, and procurement relating to assistive technologies. The authors argue that the provision of assistive technologies should be an iterative process in order to ensure PWDs constantly possess the upgraded, required assistive technologies to access information. The research - using three different case studies in the developing areas of the Pacific Islands - used qualitative data obtained from videos, documents, and participant observation to ascertain the impact of assistive technologies on accessibility. In another study, Chaudhry and Shipp (2005) conducted a comparative qualitative assessment of how the visually impaired can have equal access to the digital society in US and India. Using a cross-culture perspective, the study combined literature synthesis, personal disability experience, and observation of PWDs to understand the accessibility phenomenon for PWDs in the digital information society. They argued for the need to examine the interplay between society, technology and PWDs in order to address their accessibility needs.

There were three studies which employed a mixed method approach to understand the accessibility phenomenon. For example, Abu-Doush et al. (2013) employed observation and interviews with 20 visually impaired students to understand the challenges they face when accessing E-government services in Jordan. They observed participants as they performed specific tasks on various Egovernment websites. In addition, they conducted a survey with web developers and webmasters to discover their perceptions of accessibility. The interview results showed that PWDs had serious challenges accessing E-government websites, while the survey revealed weak understanding of accessibility on the part of web developers. Figure 2 presents methodologies identified from the literature synthesis. 


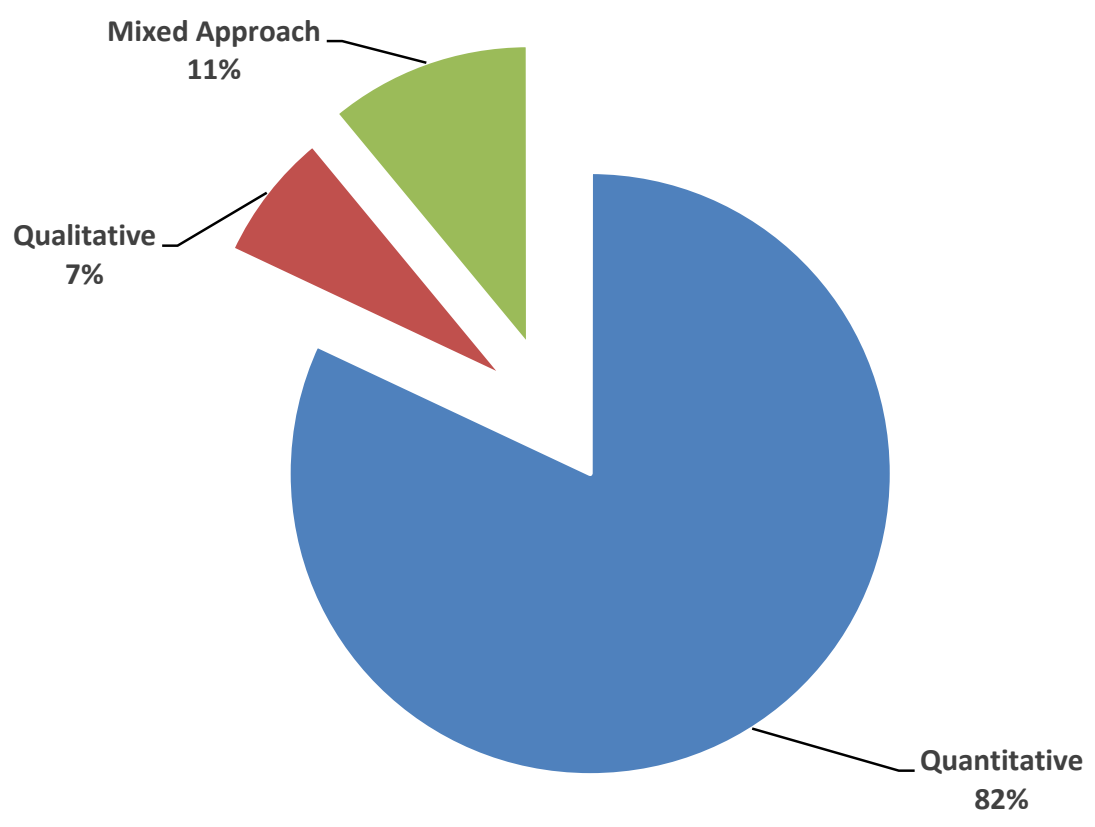

Figure 2: Summary of research methodologies

\section{RESEARCH TOOLS}

From the analysis, most researchers $(86 \%)$ used automatic tools in order to detect accessibility errors on E-government websites. In these studies, automatic tools such as EvalAccess, Bobby, Web Accessibility Evaluation Tool (WAVE), Tests de Accessibilidad Web (TAW), and AChecker were employed. Using these tools, researchers tested for accessibility of E-government websites against international standards such as WCAG 1.0, WCAG 2.0 and Section 508. WCAG defines three levels of priority for accessibility: Levels A, AA, and AAA. According to WCAG, Level A corresponds to a minimum accessibility score for PWDs; Level AA to a moderate score; and Level AAA to the highest score. The study also revealed that different automatic tools may provide varying accessibility results for the same website. By way of a typical example, Baowaly and Bhuiyan (2012) evaluated accessibility of ten E-government websites in Bangladesh using EvalAccess and AChecker. The study showed that none of the E-government websites were accessible for PWDs using AChecker, while EvalAccess evaluation indicated five websites conformed to Level A. Using automatic tools, researchers revealed specific design errors on E-government websites that would need retrofitting to make them accessible to PWDs.

Three researchers (11\%) examined the perceptions of webmasters/developers as key stakeholders in the development of E-government to find out how their understanding of accessibility affected the way they designed. The study showed most webmasters/developers neither perceived accessibility as a priority nor a necessary requirement. Lack of education and awareness of accessibility standards and accessibility as a whole also contributed to this blind spot in their perception. Freire et al. (2008), in their study on accessibility perceptions in Brazil, stressed the need boost accessibility awareness among webmasters/developers and all stakeholders involved in E-government project development at large.

As illustrated in Figure 3, only one study (Baguma et al. 2007) adopted the use of a model, namely, the Web Accessibility Integration Model (WAIM) to identify accessibility gaps from different perspectives. The study reveals that most webmasters $(67 \%)$ in Uganda are not familiar with any accessibility standards. The remaining 33\%, who have knowledge of accessibility standards, had yet to create any accessible website. According to Baguma et al. (2007) the lack both of relevant policies and edu- 
cation on accessibility does not compel web developers to design accessible websites. They also indicated other factors, such as inadequate funds, high cost of ICT infrastructure, and lack of expertise, all contribute to the lack of access.

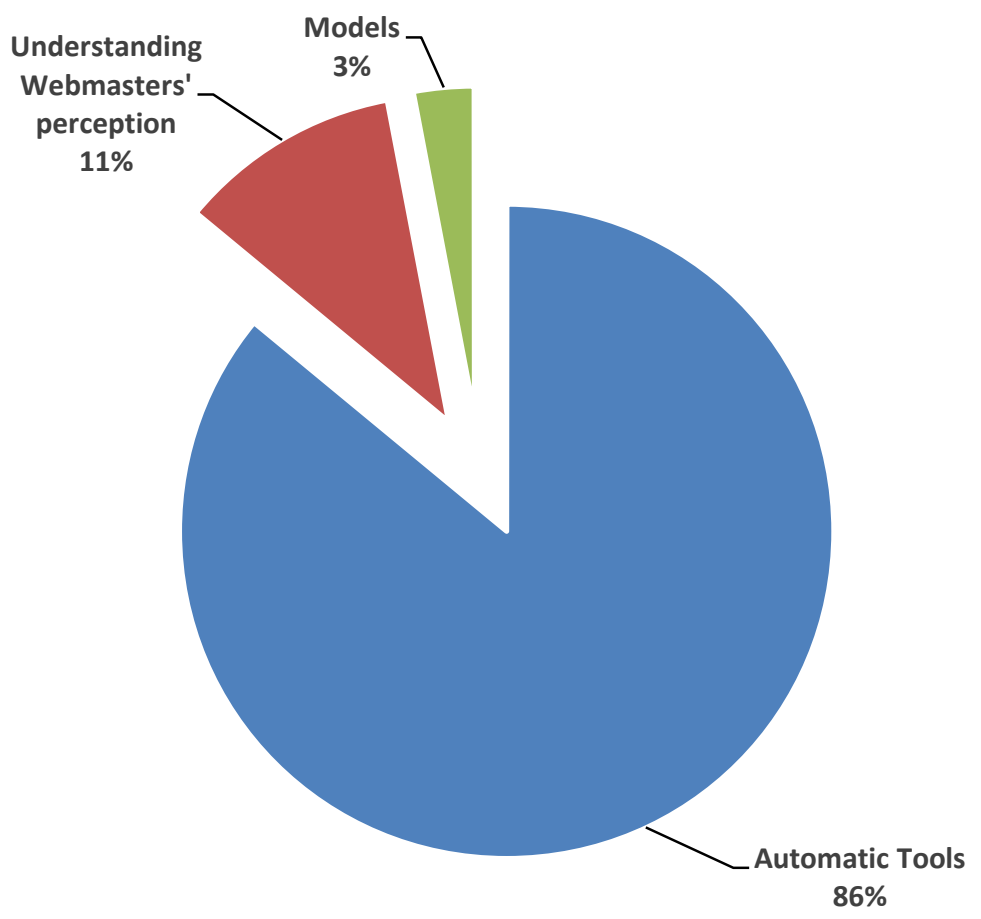

\section{DisCUSSION}

Figure 3: Summary of research tools

The purpose of this study was to examine how knowledge about E-government accessibility for PWDs, particularly in developing countries, is arrived at. The study aimed specifically to identify key research foci and perspectives used when studying this phenomenon in developing countries. The findings show that the majority of studies paid attention to the evaluation of websites, specifically how they meet the accessibility guidelines proposed by international organizations. In addition, there was a consistent reliance on a quantitative ontological stance with an overwhelming $82 \%$ of the articles using techniques such as questionnaires and surveys to elicit their understanding of the Egovernment accessibility phenomenon. Although these findings provide some enlightenment as to the phenomenon, there remains a gap in comprehending how various stakeholders understand the issue of accessibility of E-government websites, specifically to PWDs. Whilst examining the problem using quantitative approaches, researchers tend to become passive in the process of understanding what an accessible E-government really means to each stakeholder, as they are usually far from the context which they are studying (Kanellis \& Papadopoulos, 2009). When E-government accessibility studies are conducted in such a manner, focus is always placed on the supply side, neglecting the demand side where PWDs can be involved (Makoza \& Chigona, 2013; Reddick, 2005). The limited number of studies following an interpretivist or a mixed method approach is problematic for the developing countries, not only because these two approaches endorse the subject matter of inquiry by acknowledging "the world of consciousness and humanly created meanings" (Ngwenyama \& Lee, 1997, p. 149) - and, in so doing, give an understanding why people behave as they do within their specific cultural and contextual settings (Alvarez, 2002) - but also because "the positivist reliance on a human notion of causality and the location of generalizable scientific laws at the level of the empirical conjunction of events is inconsistent with both the experience of information systems re- 
search and the goal of understanding” (Smith, 2006, p. 196). In order for researchers to understand and adequately address accessibility of E-government in developing countries for PWDs, we advocate more studies that acknowledge the role of the context, so as to understand accessibility of Egovernment through the meanings that various stakeholders within the context assign to them. In this way, researchers acknowledge that perception shapes reality, and the perception one holds towards an object in a given context is often the same among a majority of participants within that context (Kanellis \& Papadopoulos, 2009; Orlikowski \& Baroudi, 1991). With this approach, researchers can better understand human thought and action in both social and organizational contexts (Klein \& Myers, 1999), and provide actionable solutions befitting that context. Given that accessibility is subjective (Bradbard \& Peters, 2010; Yesilada, Brajnik, Vigo, \& Harper, 2015), the use of qualitative and mixed approaches will help gain a better in-depth understanding of the perceptions among E-government implementers and the challenges PWDs face in accessing E-government services.

The findings also point to key research areas and the need to integrate them to arrive at accessible Egovernment applications. These areas, according to Figure 1, include: evaluation of websites, impact of assistive technologies, understanding webmasters' perceptions, and impact of policies. Findings show that no study examined accessibility of E-government towards PWDs by integrating these key areas and that PWDs as stakeholders are not involved in the study of E-government accessibility. Against this background, there is need for a model that will not only integrate the key areas, but include all stakeholders in the development of E-government applications. This study proposes the Egovernment Accessibility Development Model (EADM) as a way to integrate key research foci whilst being cognizant of stakeholder participation. Stakeholders are key components of this model as they include government agencies, webmasters/ web developers, and PWDs. Figure 4 illustrates the components of EADM. It consists of three major categories of influence on E-government accessibility: societal foundations, stakeholder perceptions, and actual development of E-government.

Societal foundations include the value that society places on issues of accessibility, evaluated through the education and training that web developers, and PWDs who consume the services, receive; the knowledge of government agencies regarding PWDs; and subsequently the laws and policies they make with regard to the disabled. This category also includes the affordability of assistive technologies PWDs may employ to access E-government websites, and the experience of these technologies and the training they require. Countries who have disability and web accessibility policies in place have more accessible websites than countries that do not (Abanumy et al., 2005; Kuzma et al., 2009). Assistive technologies enhance online accessibility for PWDs; however, due to the high cost of assistive technologies in developing countries, most PWDs tend to adopt readily available and affordable ones (Bengisu, 2010; Borg, Larsson, \& Östergren, 2011; Disability Rights Commission, 2004). In addition, PWDs require training in order to acquire the necessary skills in the use of assistive technologies, as PWDs sometimes perceive accessibility challenges due to inadequate training in assistive technologies (Disability Rights Commission, 2004; Scherer \& Glueckauf, 2005). As such, the societal foundation category determines the readiness of the public in terms of awareness of PWDs by all stakeholders; availability and affordability of assistive technologies that are contextualized to suit developing countries' problems; training and education targeted not only to increase awareness, but also to address the development and implementation of accessible E-government for PWDs; and the development and implementation of policy and laws that address accessibility of E-government for PWDs. The various stakeholders that are perceived as being important in addressing this challenge include the government who craft the policy and rule of law that is favorable for accessible Egovernment for PWDs.

The next major category of influence on E-government is made up of pivotal stakeholders involved in ensuring accessible E-government for PWDs. This includes the web developers, who are involved in the design, development, and maintenance of websites, and who should have the appropriate training and education related to implementing accessible E-government for PWDs. Most Egovernment systems have designers' perceptions inscribed in them (Heeks, 2005); as a results, web 
developers' knowledge and training in assistive technologies will enable them create websites that are compatible with these devices (West, 2008). Web developers should be sensitized to the challenges facing PWDs within their specific context. Web developers' perceptions inform their approach to design; design should from the very beginning aim for accessibility, rather than retrofitting after design (Rubaii-Barrett \& Wise, 2008). The other central stakeholders are the PWDs, who provide the relevant information relating to specific challenges they face and their needs, which must be addressed when making E-government accessible. The findings point to the need for web developers not only to evaluate the accessibility of their websites using automatic tools, but also to involve PWDs during the entire implementation. User involvement ensures that a more user-centered design is developed with less barriers and greater usability (Albalushi et al., 2016; Bertot et al., 2008; Henry et al., 2014).

Thirdly, the model proposes E-government application development as the final necessary construct. Societal foundations and stakeholder perceptions influence the entire applications' development processes. From start of design, evaluation through to final design, accessibility is determined by guidelines and evaluation tools developers' use. Evaluation forms an important stage of web development both during and after design (Arrue, Vigo, \& Abascal, 2008). Selection of appropriate design guidelines and evaluation tools play a useful role in developing accessible websites (Arrue et al., 2008; Paternò \& Schiavone, 2015). The process of design and evaluation helps to produce a citizen-centric design and ensure citizen satisfaction (Bertot et al., 2008; Malik et al., 2016). The model argues that if all constructs are comprehensively considered, E-government developed will be accessible to PWDs.

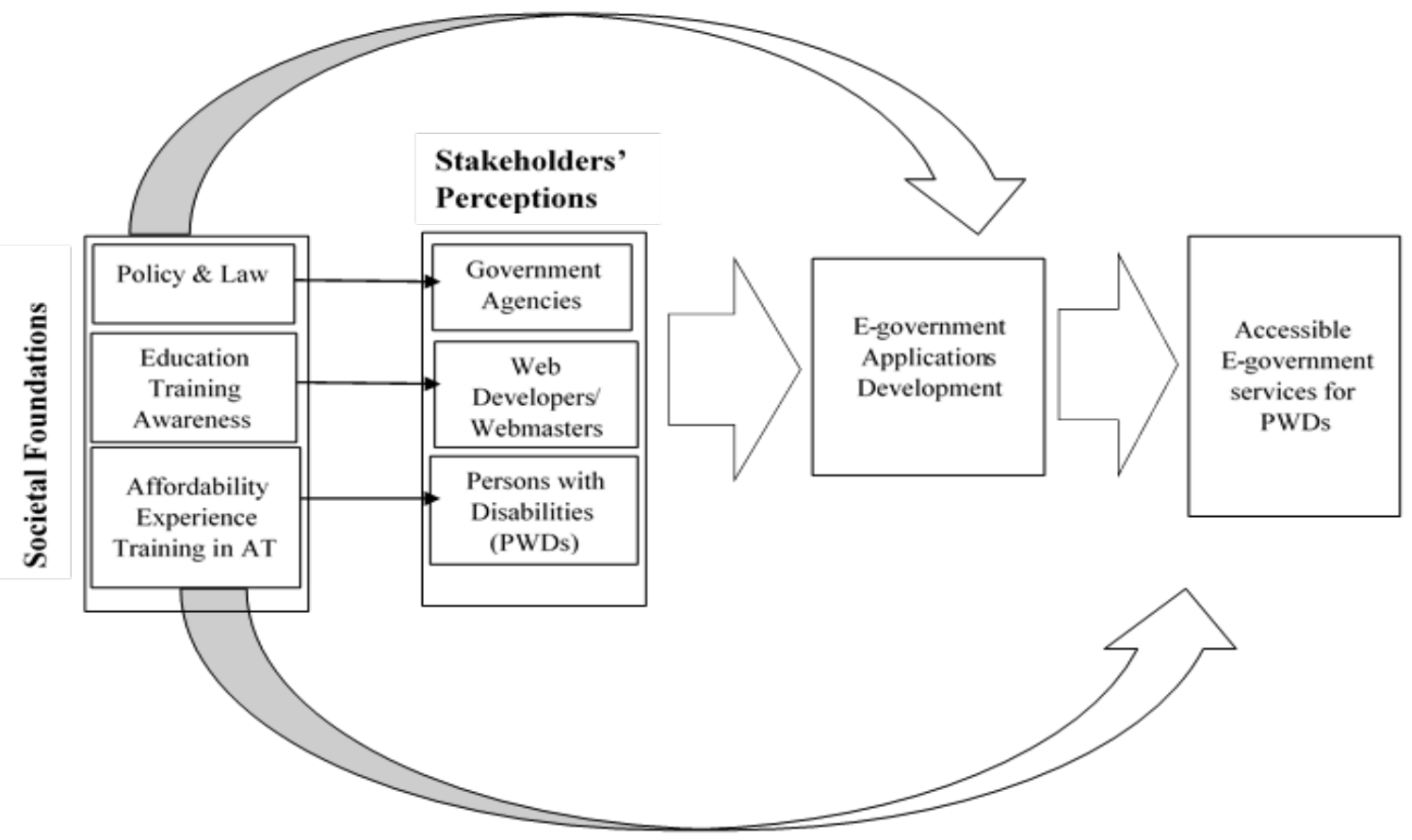

Figure 4: E-government Accessibility Development Model (EADM)

\section{CONCLUSION, SUGGESTIONS, AND FUTURE WORK}

The aim of this study was to identify the key research themes in the field of E-government accessibility for PWDs and, also, to examine how researchers go about acquiring their knowledge of this phenomenon, particularly in developing countries. Following a systematic literature review, the study identified four main themes, namely: evaluation, stakeholder perceptions, policy analysis, and social exclusion. Further, the study found that most researchers tend to follow a quantitative approach in 
examining the E-government accessibility phenomenon - an approach we perceive not to be engaging enough when one's need is to understand the context on which the study is based, so as to develop solutions that are context-specific.

With these findings, the study proposes the EADM which lays emphasis on context and inclusion of all stakeholders in the process of arriving at an accessible E-government application for PWDs. According to EADM, there is the need for society to place high priority on training and education to address awareness and knowhow among web developers and policy-makers in developing countries of contextual challenges facing PWDs. Additionally, the development and implementation of contextual policies are crucial in addressing contextual challenges facing PWDs. Although the conceptual model addresses the limitation of the previous studies we propose future empirical work in order to refine the relevance and applicability of various constructs, so as to arrive at a framework for addressing E-government accessibility for PWDs in developing countries.

The findings of this study are a contribution to the area of E-government, in the following ways:

1. We show how the phenomenon of accessibility of E-government services in developing countries has received minimal attention; and thus, we call on more researchers to engage in this niche area.

2. We provide the E-government communities with awareness about what theoretical lenses are used to conceptualize and interpret the phenomenon and we call for a critique of the relevance of these lenses.

3. We provide the E-government community with insight into the inherent assumptions, which researchers adopt in theorizing and operationalizing the E-government accessibility phenomenon and, in so doing, assess the relevance of these assumptions in developing countries' contexts.

\section{ACKNOWLEDGEMENT}

The first author would like to express gratitude to Schlumberger Foundation, Faculty of the Future Fellowship and L'Oréal-UNESCO Women in Science Sub-Saharan Africa Fellowship for funding support. The second author is grateful to the NRF foundation of South Africa for the support in the execution of the project.

\section{REFERENCES}

Abanumy, A., Al-badi, A., \& Mayhew, P. (2005). e-Government website accessibility: In-depth evaluation of Saudi Arabia and Oman. Journal of E-Government, 3(3), 99-106.

Abu-doush, I., Bany-mohammed, A., Ali, E., \& Al-betar, M. A. (2013). Towards a more accessible egovernment in Jordan: An evaluation study of visually impaired users and Web developers. Behaviour \& Information Technology, 32(3), 273-293.

Adepoju, S. A., \& Shehu, I. S. (2016). Accessibility evaluation and performance analysis of e-Government websites in Nigeria. Journal of Advances in Information Technology, 7(1), 49-53. https://doi.org/10.12720/jait.7.1.49-53

Adesola, S. (2012). Entrenching democracy and good governance: The role of ICT. Mediterranean Journal of Social Sciences, 3(15), 423. https:// doi.org/10.5901/mjss.2012.v3n15p80

Agangiba, W. A., \& Agangiba, M. A. (2013). E-governance justified. International Journal of Advanced Computer Science and Applications, 4(2), 223-225. https://doi.org/10.1017/CBO9781107415324.004

Aladwani, A. M. (2016). International Journal of Information Management Corruption as a source of eGovernment projects failure in developing countries: A theoretical exposition. International Journal of Information Management, 36(1), 105-112. https://doi.org/10.1016/j.ijinfomgt.2015.10.005 
Albalushi, T., Ali, S., Ashrafi, R., \& Albalushi, S. (2016). Accessibility and performance evaluation of e-Services in Oman using web diagnostic tools. International Journal of $U$ - and E-Service, Science and Technology, 9(7), 9-24.

Alonso, F., Fuertes, J. L., González, Á. L., \& Martínez, L. (2010). Evaluating conformance to WCAG 2.0: Open challenges. In International Conference on Computers for Handicapped Persons (pp. 417-424).

Alvarez, R. (2002). Confessions of an information worker: A critical analysis of information requirements discourse. Information and Organization, 12(2), 85-107.

Anthopoulos, L., Reddick, C. G., Giannakidou, I., \& Mavridis, N. (2016). Why e-government projects fail? An analysis of the Healthcare.gov website. Government Information Quarterly, 33(1), 161-173. https://doi.org/10.1016/i.giq.2015.07.003

Arrue, M., Vigo, M., \& Abascal, J. (2008). Including heterogeneous web accessibility guidelines in the development process. In Engineering Interactive Systems (pp. 620-637). Springer Berlin Heidelberg.

Asongu, S. A., \& Le Roux, S. (2017). Enhancing ICT for inclusive human development in Sub-Saharan Africa. Technological Forecasting and Social Change, 118, 44-54.

Baguma, R., Wanyama, T., Bommel, P. V., \& Ogao, P. (2007). Web accessibility in Uganda: A study of webmaster perceptions. In Proceedings of the 3rd Annual International Conference on Computing \& ICT Research (SREC'07) (pp. 183-197).

Bal, M., Biricik, C. G., \& Sari, A. (2015). Dissemination of information communication technologies: Mobile government practices in developing states. International Journal of Communications, Network and System Sciences, $8(13), 543-551$.

Baowaly, M. K., \& Bhuiyan, M. (2012). Accessibility analysis and evaluation of Bangladesh government websites. In Informatics, Electronics \& Vision (ICIEV), IEEE (pp. 46-51).

Basu, S. (2004). E-government and developing countries: an overview. International Review of Law, Computers \& Technology, 18(1), 109-132. https://doi.org/10.1080/13600860410001674779

Becker, J., \& Niehaves, B. (2007). Epistemological perspectives on IS research: A framework for analysing and systematizing epistemological assumptions. Information Systems Journal, 17(2), 197-214.

Beckwith, S., Dickinson, A., \& Kendall, S. (2008). The "Con" of concept analysis: A discussion paper which explores and critiques the ontological focus, reliability and antecedents of concept analysis frameworks. International Journal of Nursing Studies, 45(12), 1831-1841.

Benbasat, I., \& Weber, R. (1996). Research commentary: Rethinking “diversity” in information systems research. Information Systems Research, 7(4), 389-399.

Bengisu, M. (2010). Assistive technologies for visually impaired individuals in Turkey. Assistive Technology: The Official Journal of RESNA, 22(3), 163-71. https://doi.org/10.1080/10400435.2010.492773

Berners-Lee, T. (1997). The power of the web. Retrieved February 2, 2016, from www.w3.org/standards/Webdesign/accessibility

Bertot, J. C., Jaeger, P. T., \& McClure, C. R. (2008). Citizen-centered e-government services: benefits, costs, and research needs. In Proceedings of the 2008 International Conference on Digital Government Research (pp. 137-142).

Bhatnagar, S., \& Singh, N. (2010). Assessing the impact of e-government: A study of projects in India. Information Technologies and International Development, 6(2), 109-127.

Bloch, P. H., \& Richins, M. L. (1983). A theoretical model for the study of product importance perceptions. The Journal of Marketing, 69-81.

Borg, J., Larsson, S., \& Östergren, P.-O. (2011). The right to assistive technology: for whom, for what, and by whom? Disability \& Society, 26(2), 151-167. https://doi.org/10.1080/09687599.2011.543862

Boussarhan, I., \& Daoudi, N. (2014). The accessibility of Moroccan public websites: Evaluation of three eGovernment websites. Electronic Journal of E-Government, 12(1), 67-81.

Bradbard, D., \& Peters, C. (2010). Web accessibility theory and practice: An introduction for university faculty. The Journal of Educators Online, 7(1), 1-46. 
Burell, G., \& Morgan, G. (1979). Sociological paradigms and organisational analysis. London: Heinemann.

Butler, T., \& O'Reilly, P. (2010). Recovering the ontological foundations of the grounded theory method. In Proceedings of the $31^{\text {st }}$ International Conference on Information Systems, St. Louis, ICIS 2010. Paper 75.

Chaudhry, V., \& Shipp, T. (2005). Rethinking the digital divide in relation to visual disability in India and the United States: Towards a paradigm of information inequity. Disability Studies Quarterly, 25(25).

Chen, Y. N., Chen, H. M., Huang, W., \& Ching, R. K. (2006). E-Government strategies in developed and developing countries: An implementation framework and case study. Journal of Global Information Management, 14(1), 23-46.

Choi, H., Jae, M., Jeung, J., \& Zo, H. (2016). Rethinking the assessment of e-government implementation in developing countries from the perspective of the design-reality gap : Applications in the Indonesian eprocurement system. Telecommunications Policy, 40(7), 644-660. https://doi.org/10.1016/j.telpol.2016.03.002

Cooper, M., Sloan, D., Kelly, B., \& Lewthwaite, S. (2012). A challenge to web accessibility metrics and guidelines: Putting people and processes first. In Proceedings of the International Cross-Disciplinary Conference on Web Accessibility (p. 20).

Creswell, J. W. (2003). Research design: Qualitative, quantitative and mixed methods approaches. Thousand Oaks, CA: Sage Publications.

Cua, F. C., \& Garrett, T. C. (2008). Understanding ontology and epistemology in information systems research. In Information Systems Research Methods, Epistemology and Applications (pp. 35-56).

Cumbie, B. A., \& Kar, B. (2014). A study of local government website inclusiveness: The gap between egovernment concept and practice. Information Technology for Development, 22(1), 15-35. https://doi.org/10.1080/02681102.2014.906379

Disability Rights Commission. (2004). The Web: Access and inclusion for disabled people. London: The Stationery Office.

Dixit, P., \& Stump, J. L. (2011). A response to Jones and Smith: It's not as bad as it seems; or, five ways to move critical terrorism studies forward. Studies in Conflict \& Terrorism, 34(6), 501-511.

Dobransky, K., \& Hargittai, E. (2006). The disability divide in internet access and use. Information, Communication \& Society, 9(3), 313-334. https://doi.org/10.1080/13691180600751298

Ebrahim, Z., \& Irani, Z. (2005). E-government adoption: Architecture and barriers. Business Process Management Journal, 11(5), 589-611. https://doi.org/10.1108/14637150510619902

Evans-Cowley, J. S. (2006). The accessibility of municipal government websites. Journal of E-Government, 2(2), 75-90.

Fang, Z. (2002). E-Government in digital era: Concept, practice, and development. International Journal of the Computer, the Internet and Management, 10(2), 1-22.

Freire, A. P., Russo, C. M., \& Fortes, R. P. M. (2008, April) A survey on the accessibility awareness of people involved in web development projects in Brazil. In Proceedings of the 2008 International Cross-Disciplinary Conference on Web Accessibility (W4A) (pp. 87-96).

Goodwin, M., Susar, D., Nietzio, A., Snaprud, M., \& Jensen, C. S. (2011). Global web accessibility analysis of national government portals and ministry web sites. Journal of Information Technology \& Politics, 8(1), 41-67.

Guba, E. G., \& Lincoln, Y. (1994). Competing paradigms in qualitative research. In N. K. Denzin \& Y. S. Loncoln (Eds.), Handbook of qualitative research (pp. 105-117).

Gupta, M. P., \& Jana, D. (2003). E-government evaluation: A framework and case study. Government Information Quarterly, 20(4), 365-387. https://doi.org/10.1016/j.giq.2003.08.002

Gyaase, P. O., \& Gyamfi, S. A. (2012). Transparency, equity and accessibility to secondary education in Ghana through E-Governance: Stakeholder perspectives of the Computerised school selection and placement system (CSSPS) in Ghana. International Journal of Basic Education, 2(2), 104-116. 
Heeks, R. (2003). Most egovernment-for-development projects fail: How can risks be reduced. iGovernment Working Paper Series, IDPM, University of Manchester, 14, 1-19.

Heeks, R. (2005). e-Government as a Carrier of Context. Journal of Public Policy, 25(1), 51-74. https://doi.org/10.1017/S0143814X05000206

Heeks, R. (2010). An ICTD ranking table. Retrieved November 4, 2015, from http://itidjournal.org/itid/article/viewFile/643/278

Henry, S. L., Abou-zahra, S., \& Brewer, J. (2014). The role of accessibility in a universal web. Proceedings of the 11th Web for All Conference. ACM.

Hirschheim, R. (1985). Information systems epistemology: An historical perspective. In E. Mumford, R. Hirschheim, G. Fitzgerald, \& A. T. Wood-Harper (Eds.), Research methods in information systems (pp. 13-35).

Hirschheim, R., Klein, H. K., \& Lyytinen, K. (1995). Information systems development and data modeling: Conceptual and philosophical foundations. Cambridge University Press.

Hong, S. G., Trimi, S., Kim, D. W., \& Hyun, J. H. (2015). A Delphi study of factors hindering web accessibility for persons with disabilities. Journal of Computer Information Systems, 55(4), 28-34.

Hoque, R. M., \& Sorwar, G. (2015). ICT based e-government services for rural development: A study of union information and service center (UISC) in Bangladesh. The Electronic Journal of Information Systems in Developing Countries, 71(8), 1-19.

Ismailova, R. (2017). Web site accessibility, usability and security: a survey of government web sites in Kyrgyz Republic. Universal Access in the Information Society, 16(1), 257-264. https://doi.org/10.1007/s10209-015$\underline{0446-8}$

Jacko, J. A., \& Vitense, H. S. (2001). A review and reappraisal of information technologies within a conceptual framework for individuals with disabilities. Universal Access in the Information Society, 1(1), 56-76.

Jaeger, P. T. (2006). Assessing Section 508 compliance on federal e-government Web sites: A multi-method, user-centered evaluation of accessibility for persons with disabilities. Government Information Quarterly, 23(2), 169-190. https://doi.org/10.1016/i.giq.2006.03.002

Janssen, M., Van Der Voort, H., \& van Veenstra, A. F. (2015). Failure of large transformation projects from the viewpoint of complex adaptive systems: Management principles for dealing with project dynamics. Information Systems Frontiers, 17(1), 15-29.

Joi, L. A. (2004). Bridging the digital divide: Some initiatives in Brazil. Electronic Government, an International Journal, 1(3), 300-315.

Kaaya, J. (2004). Implementing e-Government services in East Africa: Assessing status through content analysis of government websites. Electronic Journal of E-Government, 2(1), 39-54.

Kanellis, P., \& Papadopoulos, T. (2009). Conducting research in information systems: An epistemological journey. In A. Cater-Steel \& L. Al-Hakim (Eds.), Information systems research methods, epistemology, and applications (pp. 1-34).

Kaplan, B., \& Maxwell, J. A. (1994). Qualitative research methods for evaluating computer information systems. In J. G. Anderson, C. E. Aydin, \& S. J. Jay (Eds.), Evaluating health care information systems: Methods and applications (pp. 45-68). Sage, Thousand Oaks, CA.

Kaplan, B., \& Maxwell, J. A. (2005). Qualitative research methods for evaluating computer information systems. In C. E. Aydin (Ed.), Evaluating the organizational impact of healthcare information systems (pp. 30-55).

Kelliher, F. (2011). Interpretivism and the pursuit of research legitimisation: An integrated approach to single case design. In A. Bryant (Ed.), Leading issues in business research methods (pp. 45-110).

Kelly, B., Phipps, L., \& Howell, C. (2005). Implementing a holistic approach to e-learning accessibility. In Proceedings of the 12th International Conference of the Association for Learning Technology. Manchester, England.

Kettani, D. (2014). EGovernment Applications in the African Context. 
Klein, H. K., \& Myers, M. D. (1999). A set of principles for conducting and evaluating interpretive field studies in information systems. Management Information Systems Quarterly, 23(1), 67-93.

Kumar, M., \& Sinha, O. P. (2007). M-Government - Mobile technology for e-Government. In International Conference on E-Government (pp. 294-301).

Kuzma, J., Yen, D., \& Oestreicher, K. (2009). Global e-government web accessibility: An empirical examination of EU, Asian and African sites. In Proceedings of the $2^{\text {nd }}$ International Conference on Information and Communication Technologies and Accessibility, pp 1-6.

Lazar, J., Dudley-sponaugle, A., \& Greenidge, K. (2004). Improving web accessibility: a study of webmaster perceptions. Computers in Human Behavior, 20(2), 269-288. https://doi.org/10.1016/j.chb.2003.10.018

Legge, J. S. J., \& Devore, J. (1987). Measuring productivity in U.S. public administration and public affairs programs 1981-1985. Administration and Society, 19(2), 147-156.

Leist, E., \& Smith, D. (2014). Accessibility issues in e-government. In International Conference on Electronic Government and the Information Systems Perspective. Springer International Publishing.

Leung, P., Owens, J., Lamb, G., Smith, K., Shaw, J., \& Hauff, R. (1999). Assistive technology: Meeting the technology needs of students with disabilities in post-secondary education. Canberra: Department of Education, Training and Youth Affairs.

Makoza, F., \& Chigona, W. (2013). Accessibility of e-Government websites: Case of Malawi. In Proceedings of the 15th Annual Conference on World Wide Web Applications (pp. 4-15).

Malik, B. H., Shuqin, C., Mastoi, A. G., Gul, N., \& Gul, H. (2016). Evaluating citizen e-satisfaction from egovernment services: A case of Pakistan. European Scientific Journal, 12(5), 346-370. https://doi.org/10.19044/esj.2016.v12n5p346

Markus, M. L. (1994). Electronic mail as the medium of managerial choice. Organization Science, 5(4), 502-527.

Mates, P., Lechner, T., Rieger, P., \& Pěkná, J. (2013). Towards e-Government project assessment: European approach. Proceedings of Rijeka Faculty of Economics: Journal of Economics \& Business (31:1)

Mistry, J. J., \& Jalal, A. (2012). An empirical analysis of the relationship between e-government and corruption. International Journal of Digital Accounting Research, 12(3), 145-176. https://doi.org/10.1108/eb018884

Mittal, P., \& Kaur, A. (2013). E-Governance - A challenge for India. International Journal of Advanced Research in Computer Engineering \& Technology (IJARCET), 2(3), 1196-1199.

Morgan, G., \& Smircich, L. (1980). The case for qualitative research. Academy of Management Review, 5(4), 491500.

Muddiman, D. (2000). Theories of social exclusion and the public library. In M. Dudley (Ed.), Public libraries and resilient cities (pp.1-15).

Mutula, S. (2013). Ethical dimension of the information society: Implications for Africa. In Information Ethics in Africa: Cross-Cutting Themes (pp. 29-42). Pretoria.

Myers, M. D. (1997). Qualitative research in information systems. Management Information Systems Quarterly, 21(2), 241-243.

Myers, M. D., \& Klein, H. K. (2011). A set of principles for conducting critical research in information systems. Management Information Systems Quarterly, 35(1), 17-36.

Ndou, V. (2004). E-government for developing countries: Opportunities and challenges. The Electronic Journal on Information Systems in Developing Countries, 18(1), 1-24.

Ngulube, P. (2007). The nature and accessibility of e-government in sub-Saharan Africa. International Review of Information Ethics, 7(9), 1-13.

Ngwenyama, O. K. (1991). The critical social theory approach to information systems: problems and challenges. In H. E. Nissen, H. K. Klein, \& R. Hirschheim (Eds.), Information systems research: Contemporary approaches and emergent traditions (pp. 267-280). 
Ngwenyama, O. K., \& Lee, A. S. (1997). Communication richness in electronic mail: Critical social theory and the contextuality of meaning. Management Information Systems Quarterly, 145-167.

Nkohkwo, Q. N., \& Islam, M. S. (2013). Challenges to the successful implementation of e-government initiatives in Sub-Saharan Africa: A literature review. Electronic Journal of e-Government, 11(2), 253-267.

Nord, J. H., \& Nord, G. D. (1995). MIS research: Journal status and analysis. Information and Management, 29(1), $29-42$.

Okoli, C., \& Schabram, K. (2010). A guide to conducting a systematic literature review of information systems research Sprouts: Working Papers on Information Systems, 10(26). http://sprouts.aisnet.org/10-26

Olalere, A., \& Lazar, J. (2011). Accessibility of U.S. federal government home pages: Section 508 compliance and site accessibility statements. Government Information Quarterly, 28(3), 303-309. https://doi.org/10.1016/j.giq.2011.02.002

Orlikowski, W. J., \& Baroudi, J. J. (1991). Studying information technology in organizations: Research approaches and assumptions. Information Systems Research, 2(1), 1-28.

Otniel, D. (2015). The challenges of e-government 2.0 projects in Romania: An insight. Annals-Economy Series, 4, $24-29$

Pal, J., Vartak, A., Vyas, V., Chatterjee, S., Paisios, N., \& Cherian, R. (2010). A ratification of means: International law and assistive technology in the developing world. In 4th ACM/IEEE International Conference on Information and Communication Technologies and Development (pp. 1-10).

Paternò, F., \& Schiavone, A. G. (2015). The role of tool support in public policies and accessibility. Interactions, 22(3), 60-63.

Power, C., Freire, A., Petrie, H., \& Swallow, D. (2012). Guidelines are only half of the story: Accessibility problems encountered by blind users on the web. In Proceedings of the SIGCHI Conference on Human Factors in Computing Systems (pp. 433-442).

Ratliffe, K. T., Rao, K., Skouge, J. R., \& Peter, J. (2012). Navigating the currents of change: Technology, inclusion, and access for people with disabilities in the Pacific. Information Technology for Development, 18(3), 209225.

Reddick, C. G. (2005). Citizen interaction with e-government: From the streets to servers? Government Information Quarterly, 22(1), 38-57.

Rorissa, A., \& Demissie, D. (2010). An analysis of African e-Government service websites. Government Information Quarterly Journal, 27(2), 161-169. https://doi.org/10.1016/i.giq.2009.12.003

Rubaii-Barrett, N., \& Wise, L. R. (2008). Disability access and e-government: An empirical analysis of state practices. Journal of Disability Policy Studies, 19(1), 52-64. https://doi.org/10.1177/1044207307311533

Scherer, M. J., \& Glueckauf, R. (2005). Assessing the benefits of assistive technologies for activities and participation. Rehabilitation Psychology, 50(2), 132-141. https://doi.org/10.1037/0090-5550.50.2.132

Schuppan, T. (2009). E-Government in developing countries: Experiences from sub-Saharan Africa. Government Information Quarterly, 26(1), 118-127. https://doi.org/10.1016/j.giq.2008.01.006

Scotland, J. (2012). Exploring the philosophical underpinnings of research: Relating ontology and epistemology to the methodology and methods of the scientific, interpretive, and critical research paradigms. English Language Teaching, 5(9).

Seale, J. (2006). A contextualised model of accessible e-learning practice in higher education institutions. Australasian Journal of Educational Technology, 22(2), 268-288.

Shi, Y. (2007). The accessibility of Chinese local government Web sites: An exploratory study. Government Information Quarterly, 24(2), 377-403. https://doi.org/10.1016/i.giq.2006.05.004

Smith, M. L. (2006). Overcoming theory-practice inconsistencies: Critical realism and information systems research. Information and Organization, 16(3), 191-211. 
Stanforth, C. (2006). Using actor-network theory to implementation in developing countries. Information Technologies \& International Development, 3(3), 35-60.

Stewart, R., Narendra, V., \& Schmetzke, A. (2005). Accessibility and usability of online library databases. Library Hi Tech, 23(2), 265-286. https://doi.org/10.1108/07378830510605205

Sullivan, K. (2011). The prevalence of the medical model of disability in society. Retrieved May 25, 2015, from http://digitalcommons.olin.edu/ahs capstone 2011/13

Tan, H., Wilson, A., \& Olver, I. (2009). Ricoeur's theory of interpretation: An instrument for data interpretation in hermeneutic phenomenology. International Journal of Qualitative Methods, 8(4), 1-15.

Thakur, S., \& Singh, S. (2013). Study of some e-government activities in South Africa. African Journal of Computing \& ICT, 6(2), 41-54.

Tolbert, C. J., \& Mossberger, K. (2006). The effects of e-government on trust and confidence in government. Public Administration Review, 66(3), 354-369.

UNESCO. (2014). Disability data and statistics, monitoring and evaluation: The way forward - A disability-inclusive agenda towards 2015 and beyond.

Verdegem, P., \& Verleye, G. (2009). User-centered E-Government in practice: A comprehensive model for measuring user satisfaction. Government Information Quarterly, 26(3), 487-497. https://doi.org/10.1016/j.giq.2009.03.005

W3C. (1999). Web content accessibility guidelines 1.0. Retrieved May 12, 2015, from http://www.w3.org/TR/WCAG10/

Walsham, G. (1995). The emergence of interpretivism in IS research. Information systems research, 6(4), 376-394.

Watling, S. (2011). Digital exclusion: Coming out from behind closed doors. Disability \& Society, 26(4), 491-495. https://doi.org/10.1080/09687599.2011.567802

Weerakkody, V., Dwivedi, Y. K., \& Kurunananda, A. (2009). Implementing e-government in Sri Lanka: Lessons from the UK. Information Technology for Development, 15(3), 171-192.

West, D. M. (2008). Equity and accessibility in e-government. Journal of E-Government, 1(2), 31-43. https://doi.org/10.1300/J399v01n02

Yesilada, Y., Brajnik, G., Vigo, M., \& Harper, S. (2015). Behaviour \& information technology exploring perceptions of web accessibility: A survey approach. Behaviour \& Information Technology, 34(2), 119-134.

https://doi.org/10.1080/0144929X.2013.848238

\section{BIOGRAPHIES}

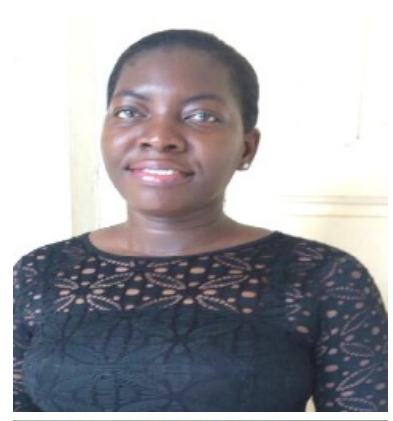

Millicent Agangiba is a $\mathrm{PhD}$ researcher at The University of Cape Town and a lecturer at The University of Mines and Technology, TarkwaGhana. Her research is centered on interaction and accessibility, particularly in the areas of E-government, E-learning, and Information and Communication Technologies for persons with disabilities in developing countries.

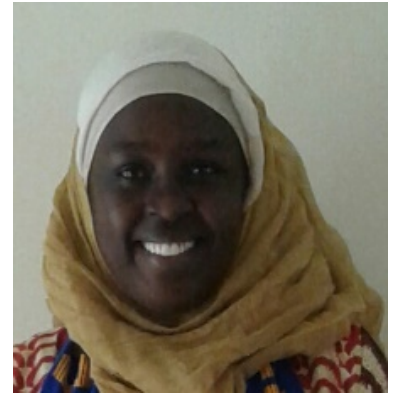

Dr. Salah Kabanda is a Senior lecturer from The University of Cape Town, South Africa. Her research interest is in the adoption, use, and consequence of ICTs in business and in government in developing countries. 